\title{
Лариса Грень
}

доктор наук з державного управління, доцент, професор кафедри педагогіки і психології управління соціальними системами ім. академіка І. Зязюна, Національний технічний університет “Харківський політехнічний інститут”;

Харків, Україна

ORCID: 0000-00034466-6018

E-mail:mega_lgren@ukr.net

\section{Халіда Курбанова}

аспірант кафедри педагогіки і психології управління соціальними системами iм. академіка I. Зязюна, Національний технічний університет

"Харківський політехнічний інститут"; Харків, Україна

E-mail: kuntesterr@gmail.com

\section{ПРОФЕСІЙНА КОМПЕТЕНТНІСТЬ МАЙБУТНІХ ІНЖЕНЕРІВ ХІМІЧНОГО ПРОФІЛЮ У ЗАКЛАДАХ ВИЩОЇ ОСВІТИ: АНАЛІЗ ТЕМАТИЧНОГО СПРЯМУВАННЯ НАУКОВОЇ ЛІТЕРАТУРИ}

Анотація: стаття присвячена з'ясуванню тематичного спрямування наукової літератури 3 формування професійної компетентності майбутніх інженерів хімічного профілю у закладах вищої освіти як вітчизняних дослідників, так і дослідників інших країн (монографії, дисертаційні дослідження); наведено класифікацію напрямів дисертаційних досліджень із формування професійної компетентності майбутніх інженерів хімічного профілю у закладах вищої освіти; доведено необхідність подальших ретельних пошуків науковців із питань формування професійної компетентності майбутніх інженерів хімічного профілю у закладах вищої освіти. Перспективними напрямами формування професійної компетентності майбутніх інженерів хімічного профілю у закладах вищої освіти є використання в освітньому процесі міжнародного досвіду з питань формування професійної компетентності та підготовки майбутніх інженерів хімічного профілю у закладах вищої освіти.

Ключові слова: професійна компетентність, майбутні інженери хімічного профілю, монографії, дисертаційні дослідження, вітчизняний та зарубіжний досвід.

\section{Larissa Gren}

doctor in public management, associated professor, professor of pedagogy and psychology of management of social systems academician I. Zyazyun, National Technical University

"Kharkiv Polytechnic Institute"; Kharkiv, Ukraine

E-mail:mega_lgren@ukr.net

\section{Khalida Kurbanova}

graduate student of the department of pedagogy and psychology of management of social systems academician I. Zyazyun, National Technical University

"Kharkiv Polytechnic Institute"; Kharkiv, Ukraine

E-mail: kuntesterr@gmail.com

(C) Лариса Грень, Халіда Курбанова, 2021 


\title{
PROFESSIONAL COMPETENCE OF FUTURE CHEMICAL ENGINEERS IN HIGHER EDUCATION INSTITUTIONS: THE ANALYSIS OF THE THEMATIC DIRECTION OF THE SCIENTIFIC LITERATURE
}

\begin{abstract}
: the article is devoted to the analysis of the thematic direction of the scientific literature on the formation of professional competence of future chemical engineers in higher education institutions of both domestic researchers and researchers from other countries (monographs, dissertation research); the classification of dissertation researches directions on the formation of professional competence of future chemical engineers in institutions of higher education is given; the necessity of further thorough researches of scientists on the issues of formation of professional competence of future chemical engineers in higher education institutions is proved. Promising areas of professional competence of future chemical engineers in higher education are use of international experience in the formation of professional competence and training of future chemical engineers in higher education in the educational process.

Key words: professional competence; future chemical engineers, monographs; dissertation research; domestic and foreign experience.
\end{abstract}

\section{Лариса Грень, Халида Курбанова}

\section{ПРОФЕССИОНАЛЬНАЯ КОМПЕТЕНТНОСТЬ БУДУЩИХ ИНЖЕНЕРОВ ХИМИЧЕСКОГО ПРОФИЛЯ В УЧРЕЖДЕНИЯХ ВЫСШЕГО ОБРАЗОВАНИЯ: АНАЛИЗ ТЕМАТИЧЕСКОГО НАПРАВЛЕНИЯ НАУЧНОЙ ЛИТЕРАТУРЫ}

Аннотащия: статья посвящена анализу тематического направления научной литературы по формированию профессиональной компетентности будущих инженеров химического профиля в учреждениях высшего образования как отечественных исследователей, так и исследователей других стран (монографии, диссертационные исследования); приведена классификация направлений диссертационных исследований по формированию профессиональной компетентности будущих инженеров химического профиля в учреждениях высшего образования; доказана необходимость дальнейших тщательных поисков ученых по вопросам формирования профессиональной компетентности будущих инженеров химического профиля в учреждениях высшего образования. Перспективными направлениями формирования профессиональной компетентности будущих инженеров химического профиля в учреждениях высшего образования является использование в образовательном процессе международного опыта по вопросам формирования профессиональной компетентности и подготовки будущих инженеров химического профиля в учреждениях высшего образования.

Ключевые слова: профессиональная компетентность, будущие инженеры химического профиля, монографии, диссертационные исследования, отечественный и зарубежный опыт.

\section{Larissa Gren, Khalida Kurbanova}

An extended abstract of the paper on subject of:

"Professional competence of future chemical engineers in higher education institutions: the analysis of the thematic direction of the scientific literature"

Problem setting. One of the most important indicators of state efficiency is qualitative changes in educational policy in accordance with the real needs of the labor market and the requirements for professional competence of graduates of higher education 
institutions. The distinguished factors affect all components of professional training of future engineers of higher education institutions and chemical engineers, in particular.

Recent research and publications analysis. The scientific works of domestic and foreign researchers are devoted to the problems of the future technical field engineers training. They are focused on the formation of a high level of professional competence: T. Butenko [2], L. Hren [3], L. Ilyashenko [5], K. Lebedeva [9], S. Leiko [10], A. Litvinchuk [11], S. Martynenko [12], M. Minshin [14], A. Sozykina [19],V. Strelnikov [20], I. Tamozhska [21], O. Turytsia [22], I. Filimonova [23], L. Tsvirkun [25].

Highlighting the previously unresolved parts of the general problem, the article is dedicated to. Issues of professional competence cannot be limited to individual areas of research and continue to be among the popular areas of research. The issue of forming the professional competence of future chemical engineers in higher education institutions remains open.

Paper objective. The purpose of the article is to find out the content of scientific research, the topics of which are related to the formation of professional competence of future engineers in higher education institutions, and future chemical engineers, in particular.

Paper main body. One of the most important indicators of state efficiency is qualitative changes in educational policy in accordance with the real needs of the labor market and the requirements for professional competence of graduates of higher education institutions. The monographs that deserve attention are: a collective monograph led by N. Volkova "The Modelling of CompetenceBased Vocational Education in the Context of European Integration", the monograph by I. Bardus "The System of Professionally Oriented Teaching of Physics to Students of Engineering and Pedagogical Specialties of Computer Field", the monograph by G. Kashkanova "Game Forms of Training in General Technical Disciplines as a Means of Forming Students' Professional Orienta- tion", collective monograph led by O. Ovcharuk "Competence Approach in Modern Education: World Experience and Ukrainian Perspectives", the research by S. Klepko "Philosophy of Education in the European Context", the monograph by O. Mitryasova "Integrated Approach to Teaching Chemistry to Students of the Agricultural University", the monograph by V. Petruk "Theoretical and Methodological Principles of Professional Competence Formation of Specialists in Technical Specialties in the Process of Studying Fundamental Disciplines."

The analysis of the dissertation researches on the professional competence formation of future chemical engineers in higher education institutions allowed us to classify them into the following areas: dissertation researches on professional selfimprovement and formation of orientation on successful professional activity (O. Ignatiuk, L. Hren); dissertation researches on the communicative competence and business communication skills formation (T. Butenko, A. Litvinchuk, I. Tamozhska); dissertation researches on the mathematical competence formation (L. Ilyashenko, S. Martynenko, M. Minshin, S. Leiko); dissertation researches on the professional competence formation in the process of studying special disciplines (S. Chupakhin, I. Filimonova, L. Tsvirkun); dissertation researches on the professional competence formation on the basis of integrated, resource approaches (O. Turitsa, K. Lebedeva); dissertation researches on the social responsibility formation ( $G$. Sozykina).

Conclusions of the research. Firstly, the professional competence formation of future engineers in higher education institutions is constantly within the scientific attention of researchers. However, the issue the professional competence formation of future chemical engineers in higher education institutions was left out of the scientists' focus, which gives us grounds for its thorough study and coverage in our further publications. 
Secondly, the analyzed research of domestic and foreign experience of professional training of competitive specialists in the context of globalization and informatization of knowledge indicates the need to further improvement of the professional competence methodology of future engineers in higher education, inclu-

Постановка проблеми у загальному вигляді та їі зв'язок із важливими науковими завданнями. У резолюції, що затвердила новий план дій "Перетворення нашого світу: Порядок денний в області сталого розвитку на період до 2030 року" і складається із 17 цілей та 169 задач, "Гідна праця та економічне зростання" оголошено Ціллю 8, в якій зазначено: "Цілі сталого розвитку сприяють сталому економічному зростанню, підвищенню рівня продуктивності і використанню технологічних інновацій. Важливою передумовою $є$ стимулювання підприємництва і створення робочих місць" [27]. Тому одним із найбільш вагомих показників ефективності держави $\epsilon$ якісні зміни в освітній політиці відповідно до реальних потреб ринку праці та вимог до професійної компетентності випускників закладів вищої освіти. Виокремленні фактори впливають на всі компоненти професійної підготовки майбутніх інженерів закладів вищої освіти та інженерів хімічного профілю зокрема. Випускник закладу вищої освіти, інженер хімічного профілю - це фахівець, професійна компетентність якого має інтегративний характер: він володіє високим рівнем професійних знань, умінь, навичок, розуміє весь спектр економічних, соціально-психологічних, екологічних проблем соціуму, здатний до творчої самореалізації, нестандартного мислення, навчання протягом життя.

Аналіз останніх досліджень і публікацій, у яких започатковано розв'язання цієї проблеми і на які спирається автор. У педагогічній науці склалися визначені передумови для розробки теоретичних та ding future chemical engineers.

Thirdly, one of the promising areas for solving the problem above is the analysis of the scientific articles of domestic and foreign researchers and the use in the educational process of international experience in training future chemical engineers in higher education.

практичних аспектів вирішення проблеми формування професійної компетентності майбутніх інженерів закладів вищої освіти. Питання підготовки майбутніх спеціалістів висвітлено у наукових роботах І. Бардус [1], Н. Волкової [15], Л. Грень [29], С. Домбровської [29], О. Ігнатюк [4], Г. Кашканової [6], С. Клепко [7], Мітрясової [13], В. Мороз [29], С. Мороз [29], О. Овчарук [8], В. Петрук [17], А. Помаза-Пономаренко [29], О. Пометун [17],О. Романовського[18],А. Хуторського [24] та інших дослідників.

У дослідження проблеми підготовки майбутніх інженерів технічного профілю, що орієнтовані на формування високого рівня професійної компетентності, зробили вагомий внесок вітчизняні i зарубіжні дослідники: Т. Бутенко [2], Л. Грень [3], Л. Іляшенко [5], К. Лебедсва [9], С. Лейко [10], А. Літвінчук [11], С. Мартиненко [12], М. Міншин [14], А. Созикіна [19], В. Стрельніков [20], I. Таможська [21], О. Туриця [22], I. Філімонова [23], Л. Цвіркун [25].

Виділення невирішених раніше частин загальної проблеми, котрим присвячується дана стаття. Питання професійної компетентності не можуть бути вичерпаними у межах окремих напрямів наукових досліджень i продовжують перебувати серед популярних напрямів наукових пошуків. Відкритим залишається питання формування професійної компетентності майбутніх інженерів хімічного профілю у закладах вищої освіти.

Формулювання цілей статті (постановка завдання). Мета статті - з'ясувати змістовну спрямованість наукових досліджень, тематика яких пов'язана 3 форму- 
ванням професійної компетентності майбутніх інженерів у закладах вищої освіти, й майбутніх інженерів хімічного профілю, зокрема.

Виклад основного матеріалу дослідження 3 повним обгрунтуванням отриманих наукових результатів. Переважно велика кількість досліджень із формування професійної компетентності майбутніх інженерів у закладах вищої освіти $\epsilon$ свідченням неабиякої уваги вітчизняних та зарубіжних дослідників до відповідної проблематики.

Аналіз тематичної спрямованості наукових досліджень із формування професійної компетентності майбутніх інженерів у закладах вищої освіти можна провести за такими напрямами, а саме: аналіз наукових статей, дисертаційних досліджень, монографій тощо. 3 огляду на обмеженість обсягів цієї публікації нами було прийнято рішення про можливість зосередження на аналізі тематичного спрямування монографій та дисертаційних досліджень.

Серед досліджень, що, на нашу думку, заслуговують на увагу, є колективна монографія на чолі $3 \mathrm{H}$. Волковою "Моделювання компетентнісної професійної освіти в контексті євроінтеграції” (подано різнопланові дослідження щодо моделювання компетентнісної професійної освіти, спрямованої на становлення особистості європейського суспільства. Дослідження охоплює огляд теоретикометодологічних засад професійної освіти, вітчизняного й зарубіжного досвіду професійної підготовки конкурентоспроможних фахівців в умовах глобалізації та інформатизації знань, аналіз можливостей комп'ютерно орієнтованих технологій в інтенсифікації професійного навчання та виховання студентів закладів вищої освіти) [15].

Монографію I. Бардус "Система професійно орієнтованого навчання фізики студентів інженерно-педагогічних спеціальностей комп'ютерного профілю” присвячено теоретичному обгрунтуван- ню та розробці системи професійно орієнтованого навчання фізики майбутніх інженерів-педагогів зазначеного профілю. У роботі висвітлено методику професійно орієнтованого навчання фізики на основі міжпредметних взаємозв' язків фізики та спеціальних дисциплін за видами та функціями діяльності інженера-педагога [1].

На увагу заслуговує монографія Г. Кашканової "Ігрові форми навчання загально технічним дисциплінам як засіб формування професійної спрямованості студентів" (розглянуто питання формування професійної спрямованості студентів засобами ігрових форм у процесі вивчення загальнотехнічних дисциплін; визначено та обгрунтовано основні принципи і методи, проведено відбір i критичний аналіз оцінок ефективності формування професійної спрямованості студентів) [6].

Дослідження С. Клепко “Філософія освіти в європейському контексті" розкриває основні поняття та конятруктивні ідеї сучасної філософії освіти, подає досвід осмислення i вирішення головних іiї проблем й освітньої політики в демократичному суспільстві, визначає оптимальний шлях розвитку системи освіти України в європейському контексті; компетентнісно орієнтований підхід у науковій роботі визначено ключовою інноваційною ідеєю сучасної освіти [7].

Методологічні, теоретичні, методичні та науково-практичні засади розвитку хімічної освіти студентів вищих аграрних закладів освіти на підставі інтегрованого підходу розглянуто у дослідженні О. Мітрясової "Інтегрований підхід до навчання хімії студентів аграрного університету". Монографія висвітлює традиції, тенденції та стратегію розвитку змісту сучасної хімічної освіти; вперше в українській педагогічній науці в ній запропоновано концепцію інтегрованого підходу до вивчення хімічних дисциплін студентами-аграріями, проаналізовано зару- 
біжний досвід інтеграції змісту природничих дисциплін. Увагу приділено сутності, цілям i завданням процесів інтеграції у навчанні хімії) [13].

Колективна монографія на чолі 3 О. Овчарук "Компетентнісний підхід у сучасній освіті: світовий досвід та українські перспективи" присвячена новим напрямам розвитку змісту освіти в Україні та розвинених країн світу (подано аналіз досвіду розроблення та впровадження компетентнісно орієнтованого підходу до формування змісту загальної середньої освіти в зарубіжних країнах; проаналізовано нові надбання українських освітян щодо визначення переліку ключових компетентностей для української школи та надано рекомендації щодо їхного впровадження в навчальновиховний процес) [8].

У монографії В. Петрук “Теоретикометодичні засади формування професійної компетентності фахівців технічних спеціальностей у процесі вивчення фундаментальних дисциплін" професійну спрямованість виведено поза межі навчання та схарактеризовано через "відповідність провідного мотиву професії реальному змісту професіï" [16, с. 37]; домінантним показником професійної спрямованості визначено зміст та глибину професійного інтересу з урахуванням його положення в системі мотивів, що утворюють професійну спрямованість студента [16].

Не зважаючи на високий рівень наукового напрацювання 3 означеної проблематики, питання формування професійної компетентності майбутніх інженерів передбачають подальших ретельних пошуків і залишаються відкритими для подальших наукових розробок, особливо це стосується питань, пов'язаних із формуванням професійної компетентності майбутніх інженерів хімічного профілю у закладах вищої освіти.

Наступним напрямом аналізу до визначеного нами кола питань $є$ дисертаційне дослідження О. Ігнатюк “Теоре- тичні та методичні основи підготовки майбутнього інженера до професійного самовдосконалення в умовах технічного університету", 2010 (розроблено, науково обгрунтовано й експериментально перевірено теоретико-методичну концепцію та систему підготовки студентів ВТНЗ до професійного самовдосконалення. Конкретизовано теоретичне уявлення щодо сутності й структури готовності до професійного самовдосконалення, схарактеризовано критерії, показники і рівні іiі сформованості, визначено педагогічні умови успішності підготовки майбутнього інженера до професійного самовдосконалення в умовах закладу вищої технічної освіти: створення ефективного освітнього середовища, яке надає можливості саморозвитку i самореалізації; здійнення теоретико-методичної підготовки викладачів i студентів до формування готовності до професійного самовдосконалення; забезпечення ефективної стійкої педагогічної взаємодії суб'єктів навчального процесу; мотиваційно-ціннісне забезпечення процесу формування готовності до професійного самовдосконалення, що виникає на основі усталеного інтересу та мотивації; організація особистісно орієнтованої підготовки студентів на основі діяльнісного підходу та інтегрованої структури виробничої діяльності; запровадження інтеграційного підходу щодо вибору форм i методів підготовки у галузі особистіснопрофесійного розвитку й самовдосконалення; впровадження у процес навчання інтегрованих психолого-педагогічних та управлінських дисциплін, які за безпечують основами знань у напрямі особистісно-професійного розвитку й самовдосконалення) [4].

У дисертаційному дослідженні Л. Грень "Педагогічні умови формування у студентів вищих технічних навчальних закладів спрямованості на успішну професійну діяльність”, 2010 визначено вплив теоретично обгрунтованих й експериментально перевірених педагог- 
гічних умов формування у студентів вищих технічних закладів освіти спрямованості на успішну професійну діяльність, на якість їхньої професійної підготовки [3].

Формуванню комунікативної компетентності майбутніх інженерів присвячено дослідження Т. Бутенко “Формування комунікативної компетентності майбутніх інженерів у процесі вивчення психолого-педагогічних дисциплін”, 2011 (розглянуто сутність комунікативної компетентності як сукупності знань, умінь i навичок, що містять: функції спілкування й особливості комунікативного процесу; види, засоби спілкування; специфіку взаємодії 3 різними співрозмовниками; форми і методи ділової взаємодії; технології та прийоми впливу на людей; методи генерування ідей та інтеграції людей для конструктивної комунікації; самопрезентацію і стратегію успіху; доведено, що розвиток комунікативної компетентності $\epsilon$ необхідною умовою ефективної професійної діяльності майбутніх інженерів у процесі вивчення психолого-педагогічних дисциплін) [2].

На увагу заслуговує дисертаційне дослідження С. Мартиненко “Формування фахової компетентності майбутніх техніків у процесі вивчення дисциплін фізико-математичного циклу в авіаційному коледжі”, 2014 (теоретично обгрунтовано педагогічну технологію формування фахової компетентності майбутніх техніків-механіків у процесі вивчення дисциплін фізико-математичного циклу в авіаційному коледжі; перевірено ефективність розробленої педагогічної технології завдяки уточненню критеріїв (когнітивного, інструментального, реф.лексивного) i показників рівнів сформованості фахової компетентності зазначеного працівника та використання методів математичної статистики) [12].

У дисертаційному дослідженні I. Таможської “Формування вмінь ділового спілкування майбутніх фахівців технічного профілю у процесі вивчення соціально-гуманітарних дисциплін”, 2014 обгрунтовано й експериментально перевірено педагогічні умови формування вмінь ділового спілкування фахівців технічного профілю в процесі вивчення соціально-гуманітарних дисциплін, уточнено суть поняття "уміння ділового спілкування" фахівця як здатність спеціаліста регулювати відносини співпраці фахівців у професійній діяльності, визначати пріоритети ділової поведінки, продукувати оптимальні рішення професійних проблем відповідно до правил ділового спілкування й норм ділового етикету, швидко реагувати на запити та потреби суб'єктів зовнішнього середовища, обгрунтовано будувати ділові комунікації 3 різними представниками зовнішнього оточення [21].

У дисертаційному дослідженні С. Лейко “Формування математичної компетентності майбутніх інженерівбудівельників у процесі фахової підготовки", 2015 проведено теоретикоекспериментальне дослідження проблеми формування математичної компетентності майбутніх інженерів-будівельників у процесі фахової підготовки; з'ясовано сутність поняття "математична компетентність майбутніх інженерів-будівельників" як інтегративну властивість особистості, що поєднує кількісні та якісні показники набутих математичних знань, умінь, навичок; теоретично обгрунтовано технологію формування математичної компетентності майбутніх інженерівбудівельників у процесі фахової підготовки, що охоплює мотиваційно-цільовий, теоретико-змістовий, діагностичний, діяльнісно-практичний етапи) [10].

Формуванню проектно-конструкторської компетентності майбутнього інженера присвячено дисертаційне дослідження Л. Цвіркун “Формування проектно-конструкторської компетентності майбутніх інженерів у процесі графічної підготовки", 2017, де уточнено етапи формування проектно-конструкторської компетентності май бутнього інженера; визначено ключове для дослід- 
ження поняття - "проектно-конструкторська компетентність майбутнього інженера" - здатність, що дозволяє результативно здійснювати професійну діяльність, застосовувати сучасні системи автоматизованого проєктування на основі наявних графічних знань, умінь та навичок; готовність до подальшого збагачення та зростання свого науковопрактичного потенціалу. Виявлено комплекс педагогічних умов як іманентних складників моделі формування проєктно-конструкторської компетентності майбутніх інженерів; доведено, що обгрунтована модель формування проектно-конструкторської компетентності майбутніх інженерів у процесі графічної підготовки сприяє формуванню навчально-пізнавальної, конструкторськографічної, інформаційно-технологічної та соціально-комунікативної компетенцій у процесі графічної підготовки [25].

Не залишилась поза увагою дослідників і професійно-комунікативна компетентність. Так у дослідженні А. Літвінчук “Формування професійно-комунікативної компетентності-технологів у процесі гуманітарної підготовки" (2018) з'ясовано пріоритетність компетентнісного підходу i роль професійно-комунікативної компетентності у системі професійної освіти сучасного зразка; уточнено сутність понять “компетентність", “комунікативна компетентність"; сформульовано зміст базового поняття "професійно-комунікативна компетентність майбутнього інженера-технолога"; виокремлено компоненти у структурі професійно-комунікативної компетентності майбутніх інженерів-технологів: професійно-дискурсивний, лінгвістичний, діяльнісний, лінгвосоціокультурний, інформаційнотехнологічний i стратегічний. Встановлено, що забезпечення комунікативностимулювального середовища у процесі гуманітарної підготовки здійснюється шляхом реалізації таких умов: формування позитивної мотивації студентів до оволодіння професійною комунікативною компетентністю в системі гуманітарної підготовки; педагогічне діагностування рівня сформованості комунікативних характеристик студента шляхом застосування студентоцентрованого підходу; забезпечення сучасного змісту професійно-комунікативної підготовки майбутніх інженерів-технологів у процесі вивчення гуманітарних дисциплін; використання методики предметно-мовного інтегрованого навчання у процесі вивчення гуманітарних дисциплін майбутніми інженерами-технологами [11].

Науковому аналізу проблеми формування професійної компетентності майбутніх інженерів-зв'язківців у процесі вивчення спеціальних дисциплін присвячено дослідження С. Чупахіна “Формування професійної компетентності майбутніх інженерів-зв'язківців у процесі вивчення спеціальних дисциплін” 2018 (здійснено цілісний науковий аналіз проблеми формування професійної компетентності майбутніх інженерів-зв'язківців у процесі вивчення спеціальних дисциплін; обгрунтовано організаційнопедагогічні умови формування професійної компетентності майбутніх інженерів-зв'язківців; розроблено модель формування професійної компетентності майбутніх інженерів-зв'язківців; доведено, що результатом змін у розподілі навчального часу i y технологіях навчання, постійного спілкування між студентами, викладачами i представниками замовників, яких було залучено до навчального процесу, стало підвищення рівня професійної компетентності майбутніх інженерів-зв'язківців) [27].

У дисертаційному дослідженні Г. Созикіної “Формування соціальної відповідальності майбутніх інженерів автомобільно-дорожньої галузі у процесі професійної підготовки" (2019) здійснено теоретичний аналіз проблеми та запропоновано нове вирішення наукового завдання, яке полягає у виявленні, теоретичному обгрунтуванні педагогічних умов та експериментальній перевірці їх 
впливу на сформованість соціальної відповідальності майбутніх інженерів автомобільно-дорожньої галузі у процесі професійної підготовки [19].

Проблема формування професійної компетентності майбутніх технологів харчових виробництв на засадах інтегрованого підходу стала предметом наукового дослідження О. Туриці “Формування професійної компетентності майбутніх технологів харчових виробництв на засадах інтегрованого підходу в коледжах", 2019 (розроблено та обгрунтовано модель формування професійної компетентності майбутніх технологів харчових виробництв на засадах інтегрованого підходу в колледжах; визначено та обгрунтовано педагогічні умови формування професійної компетентності фахівців харчового профілю на засадах інтегрованого підходу в коледжах; удосконалено зміст хімічних і технологічних дисциплін, форми та методи формування професійної компетентності майбутніх технологів харчових виробництв на засадах інтегрованого підходу) [22].

У дисертаійному дослідженні І. Філімонової “Формування професійної компетентності майбутніх бакалаврів харчових технологій у процесі вивчення фахових дисциплін” (2020) обгрунтовано педагогічні умови формування професійної компетентності майбутніх бакалаврів харчових технологій під час вивчення фахових дисциплін; запропоновано модель формування професійної компетентності майбутніх бакалаврів харчових технологій, що відображає зв'язок між метою, принципами побудови змісту навчання у закладах вищої освіти 3 урахуванням цілей, теорії та практики, засобів і способів навчання, форм організації навчального процесу; удосконалено наукові уявлення про суть та структуру професійної компетентності, особливості здійснення інженерно-педагогічної підготовки майбутніх бакалаврів харчових технологій у процесі вивчення фахових дисциплін у закладах вищої педагогічної освіти [23].

Вирішенню проблеми формування професійної компетентності майбутніх інженерів привчено дисертаційне дослідження К. Лебедєвої “Формування професійної компетентності майбутніх інженерів радіотехнічних спеціальностей на засадах ресурсного підходу", 2020 (здійнено теоретичний аналіз проблеми та запропоновано нове вирішення наукового завдання, яке полягає у виявленні, теоретичному обгрунтуванні педагогічних умов та експериментальній перевірці їхнього впливу на сформованість професійної компетентності майбутніх фахівців радіотехнічної галузі на засадах ресурсного підходу) [9].

3 визначеної проблематики на увагу заслуговують дисертаційні дослідження закордонних науковців. Так, у дисертаційному дослідженні Л. Іляшенко “Формування математичної компетентності майбутнього інженера 3 нафтогазової справи" (2010) обгрунтовано структуру математичної компетентності майбутнього інженера 3 нафтогазової справи, що відображає взаємозв'язок гносеологічного, праксиологічного, аксіологічного компонентів; розкрито їх змістовне наповнення; визначено змістовні та організаційно-методичні принципи, покладені в основу створення моделі, 3 урахуванням яких забезпечується результативне формування математичної компетентності майбутнього інженера; створено передумови для збагачення теорії та методики компетентнісного підходу в професійній освіті [5].

Підготовка інженерів із прогамного забезпечення обчислювальної тех.ніки та автоматизованих систем не залишається поза увагою дослідників. У дисертаційному дослідженні М. Міншина “Формування професійно-прикладної математичної компетентності майбутніх інженерів (на прикладі підготовки інженерів 3 прогамного забезпечення обчислювальної техніки та автоматизованих систем)", 2011 конкретизовано зміст 
поняття професійно-прикладної математичної компетентності майбутнього інженера як системного утворення особистості інженера, що складається із загальнонаукових, соціально-особистісних, інструментальних та професійних компетенцій, в основі яких $є$ визначення специфіки та формування етапів даної компетенції як сукупності компетенцій; дослідження відкриває теоретичні та прикладні можливості для пошуку ефективних шляхів підвищення якості математичної освіти майбутніх інженерів закладів вищої освіти на основі освітньої концепції компетентнісного підходу [14].

Проведений нами аналіз дисертаційних досліджень із формування професійної компетентності майбутніх інженерів хімічного профілю у закладах вищої освіти дозволив нам класифікувати їх за такими напрямами:

- дисертаційні дослідження 3 професійного самовдосконалення та формування спрямованості на успішну професійну діяльність (О. Ігнатюк, Л. Грень);

- дисертаційні дослідження 3 формування комунікативної компетентності та вмінь ділового спілкування (Т. Бутенко, А. Літвінчук, І. Таможська);

- дисертаційні дослідження з формування математичної компетентності (Л. Іляшенко, С. Лейко, С. Мартиненко, М. Міншин);

- дисертаційні дослідження 3 формування професійної компетентності у процесі вивчення спеціальних дисциплін (С. Чупахін, I. Філімонова, Л. Цвіркун);

- дисертаційні дослідження 3 формування професійної компетентності

\section{Список літератури:}

1. Бардус I. О. Система професійно орієнтованого навчання фізики студентів інженерно-педагогічних спеціальностей комп'ютерного профілю / I. О. Бардус // Монографія. - Бердянськ: на засадах інтегрованого, ресурсного підходів (О. Туриця, К. Лебедєва);

- дисертаційні дослідження 3 формування соціальної відповідальності (Г. Созикіна).

Висновки 3 даного дослідження i перспективи подальших розвідок у даному напрямку. Результати аналізу монографій та дисертаційних досліджень iз формування професійної компетентності майбутніх інженерів хімічного профілю у закладах вищої освіти надали можливість дійти таких висновків.

По-перше, формування професійної компетентності майбутніх інженерів у закладах вищої освіти постійно перебувають у межах кола наукової уваги дослідників. Проте, поза увагою науковців залишилось питання формування професійної компетентності майбутніх інженерів хімічного профілю у закладах вищої освіти, що дає нам підстави для його ретельного вивчення та висвітлення у подальших наших публікаціях.

По-друге, проаналізовані наукові дослідження вітчизняного й зарубіжного досвіду професійної підготовки конкурентоспроможних фахівців в умовах глобалізації та інформатизації знань свідчать про не обхідність подальшого удосконалення методики формування професійної компетентності майбутніх інженерів у закладах вищої освіти, зокрема і майбутніх інженерів хімічного профілю.

По-трете, одним із перспективних напрямів розв'язання вище означеної проблеми $\epsilon$ аналіз наукових статей вітчизняних i зарубіжних дослідників та використання в освітньому процесі міжнародного досвіду з питань підготовки майбутніх інженерів хімічного профілю у закладах вищої освіти.

ФОП Ткачук О.В. - 2014. - С. 224

2. Бутенко Т. О. Формування комунікативної компетентності майбутніх інженерів у процесі вивчення психолого-педагогічних дисциплін / Т. О. Бутенко//автореф. дис. ... канд. пед. наук : 13.00.04. - Вінниця. - 2011. - С. 22 
3. Грень Л. М. Педагогічні умови формування у студентів вищих технічних навчальних закладів спрямованості на успішну професійну діяльність / Л. М. Грень//автореф.дис....канд.пед.нау к:13.00.04.-Харків.-2010.-С. 24

4. Ігнатюк О. А. Формування готовності майбутнього інженера до професійного самовдосконалення: теорія і практика / О. А. Ігнатюк // Монографія Х. : НТУ “ХПІ”. - 2009. - С. 432

5. Иляшенко Л. К. Формирование математической компетентности будущего инженера по нефтегазовому делу / Л. К. Иляшенко // дис. ... канд. пед. наук: 13.00.08. - Сургут. - 2010 - С. 178

6. Кашканова Г. Г. Ігрові форми навчання загально технічним дисциплінам як засіб формування професійної спрямованості студентів/Г.Г.Кашканова, А. А. Кашканов // Монографія. Вінниця : ВНТУ. - 2012. - С. 124

7. Клепко С. Ф. Філософія освіти в європейському контексті / С. Ф. Клепко - Полтава: ПОІППО. 2006. - C. 328

8. Бібік Н. М., Ващенко Л. С., Локшина О. І. Компетентнісний підхід у сучасній освіті: світовий досвід та українські перспективи / Н. М. Бібік, Л. С. Ващенко, О. І Локшина та ін // Бібліотека з освітньої політики /; за ред. О. В. Овчарук.-К.:“К.І.С.”.-2004.-С. 112

9. Лебедєва К. О. Формування професійної компетентності майбутніх інженерів радіотехнічних спеціальностей на засадах ресурсного підходу / К. О.Лебедєва. - Харків. - 2020. - С. 378

10. Лейко С. В. Формування математичної компетентності майбутніх інженерів-будівельників у процесі фахової підготовки / С. В. Лейко // : дис ... канд. пед. наук : [спец.] 13.00.04. Полтава. - 2015. - С. 264

11. Літвінчук А. Т. Формування професійно-комунікативної компетентності майбутніх інженерів-технологів у процесі гуманітарної підготовки / А. Т. Літвінчук // дис ... канд. пед. наук : [спец.] 13.00.04. - Рівне. - 2018. - С. 283 12. Мартиненко С. А. Формування фахової компетентності майбутніх техніків у процесі вивчення дисциплін фізико-математичного циклу в авіаційному коледжі / С. А. Мартиненко // автореф. дис. ... канд. пед. наук :13.00.04. - Слов'янськ.-2014.- С. 20

13. Мітрясова О. П. Інтегрований підхід до навчання хімії студентів аграрного університету / О. П. Мітрясова // Монографія - Миколаїв : МДАУ. - 2006. - C. 295

14. Миншин М. М. Формирование профессионально-прикладной математической компетентности будущих инженеров (на примере подготовки инженеров по прогаммному обеспечению вычислительной техники и автоматизированных систем)/М. М. Миншин // автореф. дис. ... канд. пед. наук : 13.00.08. - Тольятти. - 2011. - С. 22

15. Волкова Н. П. Моделювання компе-тентнісної професійної освіти в контексті євроінтеграції [електронне видання] / кол. авт; за заг. ред. проф. Н.П. Волкової // Монографія. - Дніпро: Університет ім. А. Нобеля.-2021.-С. 356

16. Петрук В. А. Теоретикометодичні засади формування професійної компетентності фахівців технікних спеціальностей у процесі вивчення фундаментальних дисциплін / В. А. Петрук // Монографія. - Вінниця : Універсум-Вінниця. - 2006. - С. 292

17. Пометун O. I. Теорія та практика послідовної реалізації компетентнісного підходу в досвіді зарубіжних країн / О. І. Пометун // Компетентнісний підхід у сучасній освіті: світовий досвід та українські перспективи : Бібліотека з освітньої політики. K. :“К.I.C.”.-2004.-C. 15-25

18. Романовский А. Г. Инновационные педагогические технологи как основа развития философии образования / А. Г. Романовский // Теорія і практика управління соціальними системами. 2005. - № 1. - С. 47-55 
19. Созикіна Г. С. Формування соціальної відповідальності майбутніх інженерів автомобільно-дорожньої галузі у процесі професійної підготовки / Г. С. Созикіна // дис ... канд. пед. наук : [спец.]13.00.04(015).-Х.: - 2019. - С. 20

20. Стрельніков В. Ю.,ЛейкоС. В. Загально-дидактичні принципи формування математичної компетентності майбутніх інженерів-будівельників у процесі фахової підготовки / В. Ю. Стрельніков, С.В.Лейко // Витоки педагогічної майстерності : зб. наук. праць Полтав. нац. пед. університетуту імені В. Г. Короленка. - Полтава. - 2014. - Вип. 14. - C. 260-267

21. Таможська I. В. Формування вмінь ділового спілкування майбутніх фахівців технічного профілю у процесі вивчення соціально-гуманітарних дис.циплін / I. В. Таможська // дис ... канд. пед. наук : [спец.] 13.00.04. - Харків. 2014. - С. 21

22. Туриця О. О. Формування професійної компетентності майбутніх технологів харчових виробництв на засадах інтегрованого підходу в коледжах / О. О. Туриця // дис ... канд. пед. наук : [спец.] 13.00.04. - Тернопіль. 2019. - C. 472

23. Філімонова I. А. Формування професійної компетентності майбутніх бакалаврів харчових технологій у процесі вивчення фахових дисциплін [Текст] / І. А.Філімонова // дис. ... доктора філософії 015: захищена 25.08.20.- Умань. - 2020. - С. 296

24. Хуторской А. В. Ключевые компетенции как компонент личностноориентированной парадигмы образования / А. В. Хуторской // Народное образование. - 2003. - №2. - С.58-64

25. Цвіркун Л. О. Формування проєктноконструкторської компетентності майбутніх інженерів у процесі графічної підготовки / Л. О. Цвіркун // дис ... канд. пед. наук (доктора філософіï): [спец.] 13.00.04. Кременчук. - 2017. - С. 286
26. Цілі сталого розвитку [електронній ресурс]. - Режим доступу: https: //www.ua.undp.org/content/ukraine/uk/ho me/sustainable-development-goals.html

27. Чупахін C. А. Формування професійної компетентності майбутніх інженерів-зв'язківців в процесі вивчення спеціальних дисциплін / С. А. Чупахін // дис ... канд. пед. наук : [спец.] 13.00.04 (01 Освіта / Педагогіка). - Київ. - 2018. - С. 252

28. Ягупов В.В.Компетентнісний підхід до підготовки фахівців у системі вищої освіти / В. В. Ягупов, В. І. Свистун // Наукові записки НаУКМА : Педагогічні, психологічні науки та соціальна робота.2007.- Том 71.- C.3-29

29. МорозС.А.,РомановськийО.Г., Мороз В. М., Домбровська С. М., Грен Л. М., Помаза-Пономаренко А. Л. Дистанційна форма здобуття вищої освіти: аналіз думки студентів щодо якості, переваг та недоліків [електронний ресурс] / С. А. Мороз, О. Г. Романовський, В. М. Мороз, С. М. Домбровська, Л. М. Грень, А. Л. Помаза-Пономаренко // Інформаційні технології та засоби навчання. - №79 (5). 2020. - C. 276-295. - Режим доступу: https://doi.org/10.33407/itlt.v79i5.3340

\section{References:}

1. Bardus, I. O. (2014), "System of professionally oriented teaching of physics of students of engineering-pedagogical specialties of computer profile", monograph, Berdyansk, FO-P Tkachuk OV, p. 224

2. Butenko, T. O. (2011), "Formation of communicative competence of future engineers in the process of studying psychological and pedagogical disciplines", author's ref. dis. ... cand. ped. science: 13.00.04, Vinnytsia, p. 22

3. Gren, L. M. (2010), "Pedagogical conditions of formation in students of higher technical educational institutions of orientation on successful professional activity", author's ref. dis. ... cand. ped. science: 13.00 .04 , Kharkiv, p. 24 
4. Ignatiuk, O. A. (2009), "Formation of readiness of the future engineer for a profession-newselfimprovement", Theory and practice, monograph, H.: NTU“KhPI”,p. 432

5. Ilyashenko, L. K. (2010), "Formation of mathematical competence of the future engineer on oil and gas business", dis. ... cand. ped. science: 13.00 .08 , Surgut, p. 178

6. Kashkanova, G. G. (2012), "Game forms of teaching general technical disciplines as a means of forming the professional orientation of students", a monograph, Vinnytsia: VNTU, p. 124

7. Klepko, S. F. (2006), "Philosophy of education in the European context", Poltava: POIPPO, p. 328

8. Bibik, N. M., Vashchenko, L. S., Lokshina, O. I. and others (2004), "Competence approach in modern education: world experience and Ukrainian prospects", Library of educational policy, for order Ovcharuk, O.V.,K.:“K.I.C.”,p. 112

9. Lebedeva, K. O. (2020), "Formation of professional competence of future engineers of radio engineering specialties on the basis of the resource approach", Kharkiv, p. 378

10. Leiko, S. V. (2015), "Formation of mathematical competence of future civil engineers in the process of professional training", dis ... cand. ped. sciences: [spec.] 13.00.04, Poltava, p. 264

11. Litvinchuk, A. T. (2018), "Formation of professional and communicative competence of future engineers-technologists in the process of humanitarian training", dis ... cand.ped.sciences:[spec.]13.00.04,Rivne,p.283

12. Martynenko, S. A. (2014), "Formation of professional competence of future technicians in the process of studying disciplines of physical and mathematical cycle in aviation college", author's ref. dis. ... cand. ped. science: 13.00.04, Slovyansk, p. 20

13. Mitryasova, O. P. (2006), "Integrated approach to teaching chemistry to students of agrarian university", monograph, Mykolaiv: Moscow State Agrarian University, p. 295
14. Minshin, M. M. (2011), "Formation of professionally-applied mathematical competence of future engineers (on an example of preparation of engineers on software maintenance of computer equipment and automated systems)", author's ref. dis. ... cand. ped. science: 13.00 .08 , Togliatti, p. 22

15. Wolf, N. P. (2021), "Modeling of competence professional education in the context of European integration", monograph [electronic edition], col. aut; for general ed. Prof, Dnipro: Alfred Nobel University, p. 356

16. Petruk, V. A. (2006), "Theoretical and methodological principles of formation of professional competence of specialists of technical technical specialties in the process of coverage of fundamental disciplines", monograph, Vinnytsia: Universum-Vinnytsia, p. 292

17. Pometun, O. I. (2004), "Theory and practice of consistent implementation of the competence approach in the experience of foreign countries", Competence approach in modern education: world experience and Ukrainian prospects: Library of educational policy, K.: “K.I.C.”, pp.15-25

18. Romanovsky, A. G. (2005), "Innovative pedagogical technologies as a basis for the development of philosophy of education", Theory and practice of social systems management, no. 1, pp. 47-55

19. Sozykina, G. S. (2019), "Formation of social responsibility of future engineers of the road industry in the process of professional training", dis ... cand. ped. sciences: [spec.] 13.00.04 (015),Kharkiv,p. 20

20. Strelnikov, V. Yu., Leiko, S. V. (2014), "General-didactic principles of formation of mathematical competence of future civil engineers in the process of professional training", Sources of pedagogical skill: collec-tion. science. works Poltava. nat. ped. V. G. University Korolenka, Poltava, vip. 14 , pp. 260-267

21. Tamozhska, I. V. (2014), "Formation of skills of business communication of future specialists of technical profile in the process of studying social and humanitarian disciplines", dis ... cand. ped. sciences: [spec.] 
13.00.04, Kharkiv, p. 21

22. Turytsia,

O.

O. (2019),

"Formation of professional competence of future technologists of food productions on the basis of the integrated approach in colleges", dis ... cand. ped. sciences: [spec.] 13.00.04, Ternopil, p. 472

23. Filimonova, I. A. (2020), "Formation of professional competence of future bachelors of food technologies in the process of studying professional disciplines", [text]: dis. ... doctor of philosophy: 015: protected on 25.08.20, Uman, p. 296

24. Khutorskaya, A. V. (2003), "Key competencies as a component of personalityoriented paradigm of education", Narodnoe obrazovanie, no. 2, pp. 58-64

25. Tsvirkun, L. O. (2017), "Formation ofdesign competence of future engineers in the process of graphic training", dis ... cand. ped. sciences (doctor of philosophy): [special] 13.00.04, Kremenchuk, p. 286

26. Sustainable development goals, available at:https://www.ua.undp.org/content/ ukraine/uk/home/sustainable-development-

goals.html

27. Chupakhin, S. A. (2018), "Formation of professional competence of future communication engineers in the process of studying special disciplines", dis ... cand. ped. sciences: [spec.] 13.00.04 (01 Education / Pedagogy), Kyiv, p. 252

28. Yagupov, V. V. (2007), "Competence approach to training specialists in the system of higher education", Scientific notes of NaUKMA: Pedagogical, psychological sciences and social work, vol. 71, pp. 3-29

29. Moroz, S. A., Romanovs'kyj, O. G., Moroz, V. M., Dombrowska, S. M., Gren, L. M., Pomaza-Ponomarenko, A. L. (2020), "Distance form of obtaining of higher education: analysis of students' opinions on quality, advantages and disadvantages", Information Technologies and Learning Tools, no. 79 (5), pp. 276-295, available at: DOI: https://doi.org/10.33407/itlt.v79i5.3340 